Original Research

\title{
Association between Consumer Practices and Phthalate Exposure in Children and their Parents from Slovakia
}

\author{
Henrieta Hlisníková*, Miroslava Šidlovská, Branislav Kolena, Ida Petrovičová \\ Department of Zoology and Anthropology, Faculty of Natural Sciences, \\ Constantine the Philosopher University in Nitra, Slovak Republic
}

Received: 9 January 2018

Accepted: 28 February 2018

\begin{abstract}
Phthalates represent endocrine disrupting chemicals, with harmful effect on the hormonal balance of the human body. Food is a substantial source of exposure to phthalates. The aim of study was to investigate association between phthalate exposure of children and their parents from Slovakia (children $\mathrm{n}=51$, parents $\mathrm{n}=27$ ) and their consumer practices. We analysed urine samples by high performance liquid chromatography and tandem mass spectrometry (HPLC-MS/MS) to determine concentrations of phthalate metabolites monoethyl phthalate (MEP), monomethyl phthalate (MMP), mono-n-buthyl phthalate (MnBP), mono-iso-buthyl phthalate (MiBP), monocyclo-hexyl phthalate (MCHP), mono(2ethylhexyl) phthalate (MEHP), mono(2-ethyl-5-hydroxyhexyl) phthalate (MEHHP), mono(2-ethyl5-oxohexyl) phthalate (MEOHP), mono(2-ethyl-5-carboxypentyl) phthalate (MECPP) and mono(2carboxymethylhexyl) phthalate (McMHP), mono-n-octyl phthalate (MnOP) and mono-isononyl phthalate (MiNP). We observed significantly higher concentrations of di (2-ethylhexyl) phthalate (DEHP) metabolites and MiBP in children in comparison with parents $(\mathrm{p} \leq 0.05)$. We found statistically significant association between concentrations of some phthalates and consumption of food packed in the plastic containers, drinking of milk and strongest association was detected between consumption of sliced salami in a plastic package and concentrations of all DEHP metabolites $(p \leq 0.05)$. We concluded that consumption of the fat rich food stored in the plastic containers together with socioeconomic status and age could affect urinary concentration of phthalate metabolites.
\end{abstract}

Keywords: biomonitoring, phthalate metabolites, consumer practices, food containers, children and their parents from Slovakia

*e-mail: henrieta.hlisnikova@ukf.sk 


\section{Introduction}

Phthalates are plasticizers commonly used in industrial production of plastic materials [1]. Phthalates belong to the group of endocrine-disrupting chemicals that can act as exogenous hormones in the human body and can affect the concentrations of reproductive hormones and the onset of puberty [2]. Adverse effects of phthalates on human fertility cause shorter anogenital distance, cryptorchidism, and hypospadias in men [3]. Phthalates could affect masculine playbehaviour of boys, who were exposed to phthalates during prenatal ontogenesis [4]. Derivates of phthalic acid are harmful for asthma and allergy formation [5]. They can induce a higher concentration of lipids in the blood, higher BMI, and an increase in waist circumference [6]. Phthalates, especially DEHP, can also affect the onset of cancer [7]. The most sensitive windows of exposure to phthalate are found during critical periods of development, such as fetal development, early life, and puberty. Children's metabolic pathways are unable to effectively eliminate phthalate metabolites from the organism, they remain in the organism, and can influence proper development. Although developmental processes may be disturbed with exposure to phthalates, disturbance can occur after years or decades [8]. Phthalate exposure could be realized by direct contact or by migration to food, beverages, and air, and by environmental pollution [9]. People may be exposed to phthalates by ingestion, inhalation, and dermal exposure. Also, they can be exposed during intrauterine development [10]. Ingestion of food is the main route of phthalate exposure, mainly ingestion of fat-rich food products as a consequence of phthalate lipophilicity [11]. Phthalates are not chemically bound in polymers, so they can migrate into food, which is accelerated by heating [12]. The amount of phthalates in food also depends on the contamination of ingredients used in food production and processing, the production technology, the length of storage and storage temperature in the plastic containers and on the fat content of food [13]. Food represents the most remarkable source of exposure to phthalates and therefore the objective of our study was to investigate the association between consumer practices and phthalate exposure of children and their parents from Slovakia.

\section{Material and Methods}

\section{Study Population}

Our study population consisted of children and their parents from Slovakia $(\mathrm{n}=78)$, preschool-aged children $(\mathrm{n}=51)-$ girls $37.25 \%(\mathrm{n}=19)$ and boys $62.75 \%(\mathrm{n}=32)$ with age range from 1-7 years - and their parents $(n=27)$, mainly mothers. Sample and data collection was realized from May to November 2016 at three nursery schools: 2 in the region of Nitra (nursery school in Melek, nursery school in Nitra) and the nursery school in Bardejov. First-morning urine samples $(6 \times 2 \mathrm{ml})$ were collected from each proband and stored in a deep freezer at $-74^{\circ} \mathrm{C}$ until analysis.

\section{Data Collection by Questionnaire}

The questionnaire was carried out by one trained technician in order to obtain important data about consumer practices and body composition of probands. Our research was anonymous and participation of our probands was voluntary. All adult participants gave written informed consent, and the legal representatives of all children gave written informed consent prior to the study.

\section{Qualitative and Quantitative Analysis}

Urinary concentrations of 12 phthalate metabolites: monomethyl phthalate (MMP), monoethyl phthalate (MEP), monocyclohexyl phthalate (MCHP), mono-nbuthyl phthalate (MnBP), mono-iso-buthyl phthalate (MiBP), mono(2-ethylhexyl) phthalate (MEHP), mono(2-ethyl-5-oxohexyl) phthalate (MEOHP), mono(2-ethyl-5-hydroxyhexyl) phthalate (MEHHP), mono(2-etyl-5-carboxypentyl) phthalate (MECPP), mono(2-carboxymethylhexyl) phthalate (McMHP), monocyclo-hexyl phthalate (MCHP), mono-iso-nonyl phthalate (MiNP), and mono-n-octyl phthalate (MnOP) were measured. We used high-performance liquid chromatography (HPLC) and tandem mass spectrometry (MS/MS) (Infinity 1260 and 6410 triple quad instruments, (Agilent Technology) using the method reported by [14]. Briefly, $1 \mathrm{ml}$ of urine was thawed, buffered with ammonium acetate, spiked with isotopelabelled phthalate standards, $\beta$-glucuronidase enzyme (K12 E. Coli, Roche, Mannheim, Germany), and incubated $\left(37^{\circ} \mathrm{C} ; 60\right.$ minutes). Afterward, deconjugation samples were diluted with phosphate buffer $\left(\mathrm{NaH}_{2} \mathrm{PO}_{4}\right.$ in $\mathrm{H}_{3} \mathrm{PO}_{4}$ ) and loaded onto SPE cartridges (ABS Elut Nexus, Agilent). Cartridges were conditioned with acetonitrile (ACN), followed by phosphate buffer before samples were loaded. To remove hydrophilic compounds, SPE cartridges were flushed with formic acid and water. Elution of analytes was performed by using CAN and ethylacetate. Eluate was dried by nitrogen gas and reconstituted with $200 \mu \mathrm{L}$ of $\mathrm{H}_{2} \mathrm{O}$ and ACN (1:1). For HPLC we used an Agilent Infinity 1260 liquid chromatograph equipped with ZORBAX Eclipse plus phenyl-hexyl column $(2.1$ x $150 \mathrm{~mm}$, $3 \mu \mathrm{m})$. Separation was done using a non-linear gradient program of mobile phases (ACN, $0.1 \%$ acetic acid in $\mathrm{H}_{2} \mathrm{O}$ ). Agilent 6410 triplequad with electro-spray ionization was used for mass specific detection of phthalate metabolites. Precursor and product ions, collision energies, retention times, and limits of detection (LOD) are shown in Table 1. 
Table 1. Phthalate monoesters: chromatographic and mass spectrometric parameters.

\begin{tabular}{|c|c|c|c|c|c|c|c|}
\hline Compound name & Precursorion & Production & $\mathrm{F}(\mathrm{V})$ & $\mathrm{CE}(\mathrm{V})$ & Polarity & $\mathrm{RT}$ (min) & LOD \\
\hline MEP labeled & 197.1 & 79 & 60 & 15 & NEG & 11.9 & \\
\hline MEP & 193.1 & 77 & 60 & 15 & NEG & 11.9 & 5.10 \\
\hline MMP labeled & 183 & 79 & 70 & 13 & NEG & 7.9 & \\
\hline MMP & 179 & 77 & 70 & 13 & NEG & 7.9 & 4.24 \\
\hline MECPP labeled & 311.1 & 159.1 & 90 & 5 & NEG & 18.4 & \\
\hline МЕСРP & 307.1 & 159.1 & 100 & 3 & NEG & 18.4 & 0.07 \\
\hline MEHHP labeled & 297.2 & 124.1 & 105 & 12 & NEG & 18.2 & \\
\hline MEHHP & 293.1 & 121 & 105 & 12 & NEG & 18.2 & 0.25 \\
\hline MEOHP labeled & 295.1 & 124 & 90 & 10 & NEG & 18.98 & \\
\hline MEOHP & 291.2 & 121 & 100 & 10 & NEG & 18.98 & 0.22 \\
\hline MBP labeled & 225.1 & 78.9 & 90 & 10 & NEG & 18.87 & \\
\hline MBP & 221.1 & 76.9 & 90 & 10 & NEG & 18.87 & 0.75 \\
\hline McMHP labeled & 311.2 & 159.2 & 80 & 2 & NEG & 20.0 & \\
\hline McMHP & 307.2 & 159.1 & 65 & 3 & NEG & 20.0 & 0.19 \\
\hline MiNP labeled & 295.3 & 79 & 95 & 14 & NEG & 23.0 & \\
\hline MiNP & 291.2 & 141.2 & 95 & 13 & NEG & 23.0 & 0.36 \\
\hline MEHP labeled & 281.1 & 137.1 & 95 & 14 & NEG & 22.7 & \\
\hline MEHP & 277.1 & 133.9 & 90 & 14 & NEG & 22.7 & 0.40 \\
\hline MnOP labeled & 281.1 & 79 & 90 & 10 & NEG & 23.0 & \\
\hline $\mathrm{MnOP}$ & 277.1 & 127.2 & 90 & 10 & NEG & 23.0 & 0.58 \\
\hline MCHP labeled & 251 & 79.1 & 60 & 14 & NEG & 20.4 & \\
\hline MCHP & 247 & 77 & 60 & 12 & NEG & 20.4 & 0.26 \\
\hline
\end{tabular}

Legend: MEP - monoethyl phthalate, MMP - monomethyl phthalate, MECPP - mono(2-etyl-5-carboxypentyl) phthalate, MEHHP - mono(2-ethyl-5-hydroxyhexyl) phthalate, MEOHP - mono(2-ethyl-5-oxohexyl) phthalate, MBP - monbuthyl phthalate, McMHP - mono(2-carboxymethylhexyl) phthalate, MiNP - mono-iso-nonyl phthalate, MEHP - mono(2-ethylhexyl) phthalate, MnOP - mono-n-octyl phthalate, MCHP - monocyclo-hexyl phthalate, LOD- limit of detection (ng.ml ${ }^{-1}$ )

\section{Statistics}

For an evaluation of the phthalate metabolites we used Statistica 7.0. Non-parametric Mann-Whitney test was used for questions with two options. Non-parametric Kruskal-Wallis test was used for questions with multiple options. In both, a difference was considered to be statistically significant when $p \leq 0.05$.

\section{Results and Discussion}

The cohort, consisting of 78 probands, was divided in two groups: children $(\mathrm{n}=51 ; 65.38 \%)$ and adults $(\mathrm{n}=27 ; 34.62 \%)$. We evaluated exposure to metabolites of dimethyl phthalate (DMP), diethyl phthalate (DEP), dibuthyl phthalate (DnBP), dicyclohexyl phthalate (DCHP), di(2-ethylhexyl) phthalate (DEHP), dioctyl phthalate (DnOP), and diisononyl phthalate (DiNP) based on the analysis of the first morning urine samples coupled with a questionnaire. We found that the urinary concentration of detected phthalate metabolites in our probands was above the limit of detection (LOD) in $8.97 \%$ of samples for MMP, $100 \%$ of samples for MEP, $98.72 \%$ of samples for MiBP, $98.72 \%$ of samples for MnBP, $1.28 \%$ of samples for MCHP, $100 \%$ of samples for McMHP, $96.15 \%$ of samples for MEHP, $98.72 \%$ of samples for MEHHP, $98.72 \%$ of samples for MEOHP, $98.72 \%$ of samples of MECPP, and $3.85 \%$ of samples for MiNP. All samples for MnOP were below the LOD.

In analyses of children and their parents we documented significantly higher concentrations of MEHHP $(p=0.02), \operatorname{MECPP}(p=0.001)$, MEOHP $(\mathrm{p}=0.004), \operatorname{McMHP}(\mathrm{p}=0.03), \operatorname{MnBP}(\mathrm{p}=0.01)$, and $\operatorname{MiBP}(p=0.003)$ in children in comparison with their parents (which could be due to the immature metabolic pathways of children as their organism 
Table 2. Correlation of parent-child phthalate metabolites.

\begin{tabular}{|c|c|c|c|c|c|c|c|c|c|c|c|}
\hline \multicolumn{12}{|c|}{ PARENTS } \\
\hline \multirow{11}{*}{ CHILDREN } & & MMP & MEP & $\mathrm{MnBP}$ & MiBP & McMHP & MEHP & MEHHP & MEOHP & МЕСРP & MiNP \\
\hline & MMP & 0.36 & -0.13 & 0.02 & -0.20 & $-0.44 *$ & -0.23 & -0.34 & $-0.41 *$ & -0.31 & -0.07 \\
\hline & MEP & 0.05 & -0.15 & -0.37 & $-0.60 *$ & -0.34 & -0.21 & $-0.44 *$ & $-0.45^{*}$ & $-0.51 *$ & -0.17 \\
\hline & $\mathrm{MnBP}$ & -0.05 & -0.13 & -0.19 & -0.36 & -0.18 & -0.14 & -0.25 & -0.31 & -0.35 & 0.01 \\
\hline & MiBP & 0.1 & -0.1 & -0.23 & -0.37 & -0.27 & -0.06 & -0.32 & -0.36 & $-0.39 *$ & 0.20 \\
\hline & McMHP & 0.18 & -0.19 & -0.26 & -0.31 & -0.16 & -0.05 & -0.29 & -0.29 & -0.35 & 0.17 \\
\hline & MEHP & 0.25 & -0.21 & -0.14 & -0.17 & -0.09 & 0.02 & -0.12 & -0.18 & -0.18 & 0.31 \\
\hline & MEHHP & 0.12 & -0.14 & -0.17 & -0.22 & -0.06 & -0.003 & -0.23 & -0.24 & -0.30 & 0.25 \\
\hline & MEOHP & 0.1 & -0.12 & -0.16 & -0.23 & -0.07 & -0.01 & -0.22 & -0.25 & -0.31 & 0.23 \\
\hline & МЕСРP & 0.1 & -0.06 & -0.15 & -0.24 & -0.07 & 0.02 & -0.23 & -0.26 & -0.29 & 0.25 \\
\hline & MiNP & -0.08 & 0.05 & $0.46^{*}$ & 0.29 & 0.24 & 0.20 & 0.26 & 0.28 & 0.22 & $0.72 *$ \\
\hline
\end{tabular}

Legend: MMP - monomethyl phthalate, MEP - monoethyl phthalate, MnBP - mono-n-buthyl phthalate, MiBP - mono-iso-buthyl phthalate, McMHP - mono(2-carboxymethylhexyl) phthalate, MEHP - mono(2-ethylhexyl) phthalate, MEHHP - mono(2-ethyl-5hydroxyhexyl) phthalate, MEOHP - mono(2-ethyl-5-oxohexyl) phthalate, MECPP - mono(2-etyl-5-carboxypentyl) phthalate, MiNP - mono-iso-nonyl phthalate, * correlation is significant at the 0.05 level

develops) [15]. Next, they have a greater body surface:volume ratio compared to adults and a different body water:fat:muscles ratio in comparison with adults [16]. In the next step, we analysed the correlation of parent-child data (Table 2). There were significant correlations between concentrations of MMP from children and concentrations of McMHP $(\mathrm{R}=-0.04$; $\mathrm{p}=0.03)$ and $\operatorname{MEOHP}(\mathrm{R}=-0.41 ; \mathrm{p}=0.04)$ from parents. Correlations between MEP concentrations from children and concentrations of $\mathrm{MiBP}(\mathrm{R}=-0.60 ; \mathrm{p}=0.001)$, MEHHP $(\mathrm{R}=-0.44 ; \mathrm{p}=0.02)$, MEOHP $(\mathrm{R}=-0.45$; $\mathrm{p}=0.02)$, and $\operatorname{MECPP}(\mathrm{R}=-0.51 ; \mathrm{p}=0.01)$ from parents were also detected. The next significant correlation was found between concentrations of MiBP from children and concentrations of MECPP $(\mathrm{R}=-0.39 ; \mathrm{p}=0.05)$ from parents, and also concentrations of MiNP from children and $\operatorname{MnBP}(\mathrm{R}=0.46 ; \mathrm{p}=0.02)$ and MiNP $(\mathrm{R}=0.72 ; \mathrm{p}=0.001)$ from their parents.

When data were separated into groups of children and adults, a similar pattern was observed; children had higher concentrations of phthalate metabolites compared to the adults, as presented in Table 3. In our study, urinary concentrations of DEHP metabolites (medians) are comparable with Swedish [17] and Danish studies [18], but lower than in Spanish [19] and German research [20]. This could be explained by the higher frequency of DEHP industrial use in the past, which is currently being replaced by other phthalates, for example DiNP or DiDP [21]. After dividing children cohorts into subgroups according to gender, we observed higher concentrations of MEP, MiBP, MEHP, MEHHP, MECPP, and MEOHP in the group of boys, and higher concentrations of McMHP in girls; however, these results are not statistically significant. As shown in Table 4, concentrations of phthalate metabolites in our study have a similar pattern to previous children group studies [22-25] where the higher concentrations of high-molecular-weight (HMW) phthalates were detected only in boys. However, in the NHANES study [26], the higher concentrations of HMW phthalates were observed in the group of girls. On the contrary, the concentrations of low-molecular-weight phthalates (LMW) were lower in comparison with children group studies [23, 25, 27, 28]. This fact could be explained by the higher frequency of industrial usage of LMW phthalates in the past and the different age range of children. A group of children in a Brazilian study [25] was aged 6-14. In these age categories, girls tend to use even more cosmetics and personal care products in which LMW phthalates occur.

Because our sample collection was realized in two distinct regions of Slovakia (Nitra and Bardejov), we compared these regions in the next steps of analysis. We detected significantly higher concentrations of metabolites MEP $(p=0.03), \operatorname{MnBP}(p=0.01)$, MiBP $(\mathrm{p}=0.001)$, MEHP $(\mathrm{p}=0.02)$, and McMHP $(\mathrm{p}=0.03)$ in the group of children who live in the poorer region of Bardejov $(\mathrm{n}=28 ; 54.9 \%)$ in comparison with children from Nitra $(\mathrm{n}=23 ; 45.1 \%)$. We assume that this finding could be a consequence of lower socioeconomic status of probands from the eastern region compared to the probands of Nitra, where there is a higher unemployment rate (Bardejov 16.63\%; Nitra 5.12\%) [29].

Probands were also analysed according to place of residence: urban or rural. Significantly higher concentrations of $\mathrm{MnBP}$ were detected in the group of children who live in a rural area $(\mathrm{p}=0.04)$ $(\mathrm{n}=30 ; 58.82 \%$ ) in comparison with children living in urban areas $(\mathrm{n}=21 ; 41.18 \%)$. On the other hand, we observed statistically significant association 
Table 3. Comparison of phthalate metabolites $\left(\mathrm{ng} \cdot \mathrm{ml}^{-1}\right)$ between children and parents.

\begin{tabular}{|c|c|c|c|c|c|c|c|c|}
\hline & & MEP & $\mathrm{MnBP}$ & MiBP & МЕHНP & MECPP & MEOHP & MEHP \\
\hline \multirow{2}{*}{$\begin{array}{l}\text { Our research (2017) } \\
\text { Slovakia }\end{array}$} & Parents $(n=21)$ & 24.12 & 32.82 & 17.13 & 10.03 & 5.60 & 7.63 & 3.26 \\
\hline & Children $(\mathrm{n}=57)$ & 23.69 & 54.11 & 32.14 & 17.52 & 11.73 & 14.50 & 2.32 \\
\hline \multirow{2}{*}{$\begin{array}{l}\text { Myridakis et al. [40] } \\
\text { Greece }\end{array}$} & Mothers $(n=239)$ & 133.90 & 36.10 & 39.20 & 25.70 & - & 17.60 & 7.60 \\
\hline & Children $(n=239)$ & 34.40 & 23.90 & 34.40 & 30.50 & - & 20.00 & 2.80 \\
\hline \multirow{2}{*}{$\begin{array}{l}\text { Larsson et al. [17] } \\
\text { Sweden }\end{array}$} & Mothers $(\mathrm{n}=98)$ & 42.40 & 59.19 & - & 13.40 & 10.69 & 8.04 & 2.64 \\
\hline & Children $(\mathrm{n}=98)$ & 24.68 & 79.25 & - & 24.50 & 22.77 & 16.34 & 2.87 \\
\hline \multirow{2}{*}{$\begin{array}{l}\text { Polanska et al. [40] } \\
\text { Poland }\end{array}$} & Mothers $(n=165)$ & 18.70 & 3.60 & 10.30 & 2.00 & - & 1.30 & 0.20 \\
\hline & Children $(n=148)$ & 9.80 & 4.00 & 2.50 & 2.10 & - & 1.20 & 0.20 \\
\hline \multirow{2}{*}{$\begin{array}{c}\text { Enke et al. [41] } \\
\text { Germany }\end{array}$} & Mothers $(n=9)$ & 61.40 & 14.30 & 15.30 & 5.60 & 10.40 & 4.80 & 3.30 \\
\hline & Children $(\mathrm{n}=9)$ & 11.40 & 22.50 & 6.50 & 1.70 & 11.90 & 1.30 & 0.90 \\
\hline \multirow{2}{*}{$\begin{array}{l}\text { Frederiksen et al. [18] } \\
\text { Denmark }\end{array}$} & Mothers $(n=145)$ & 29.00 & 20.00 & 36.00 & 12.00 & 8.20 & 6.10 & 1.70 \\
\hline & Children $(n=143)$ & 54.00 & 32.00 & 54.00 & 23.00 & 15.00 & 12.00 & 2.00 \\
\hline \multirow{2}{*}{$\begin{array}{c}\text { Kasper - Sonnenberg et al. } \\
{[20]} \\
\text { Germany }\end{array}$} & Mothers $(n=104)$ & 53.80 & 30.90 & 43.00 & 17.30 & 20.50 & 12.90 & 4.60 \\
\hline & Children $(n=104)$ & 33.60 & 54.20 & 68.70 & 31.00 & 42.10 & 26.40 & 4.00 \\
\hline \multirow{2}{*}{$\begin{array}{l}\text { Casas et al. [19] } \\
\text { Spain }\end{array}$} & Mothers $(n=120)$ & 324.00 & 27.50 & 29.90 & 17.30 & 32.20 & 15.70 & 4.40 \\
\hline & Children $(\mathrm{n}=30)$ & 755.00 & 30.20 & 41.90 & 57.40 & 115.00 & 44.60 & 6.20 \\
\hline
\end{tabular}

Legend: MEP - monoethyl phthalate, MnBP - mono-n-buthyl phthalate, MiBP - mono-iso-buthyl phthalate; MEHHP - mono(2ethyl-5-hydroxyhexyl) phthalate, MECPP - mono(2-ethyl-5-carboxypentyl) phthalate; MEOHP - mono(2-ethyl-5-oxohexyl) phthalate, MEHP - mono(2-ethylhexyl) phthalate

betweens higher concentrations of MEHP and living in rural areas in adults ( $\mathrm{p}=0.01 ; \mathrm{n}=14 ; 51.85 \%$ ) in comparison with adults who live in urban areas ( $\mathrm{n}=13 ; 48.15 \%$ ). Our results are comparable with a South Korean study [30] where probands living in a rural area reached higher concentrations of DEHP metabolites (MEHP = $22.5 \mu \mathrm{g} / \mathrm{g}$ creatinine; $\mathrm{MEHHP}=126.5 \mu \mathrm{g} / \mathrm{g}$ creatinine; $\mathrm{MEOHP}=129.9 \mu \mathrm{g} / \mathrm{g}$ creatinine) compared to the probands from urban areas $(\mathrm{MEHP}=18.7 \mu \mathrm{g} / \mathrm{g}$ creatinine; $\mathrm{MEHHP}=106.8 \mu \mathrm{g} / \mathrm{g}$ creatinine; $\mathrm{MEOHP}=112.8 \mu \mathrm{g} / \mathrm{g}$ creatinine). However, our results are in contrast with a Chinese study [31] that found higher concentrations of HMW phthalate metabolites in probands from urban areas.

Phthalate could act as obesogens. Phthalate exposure could affect an increase of BMI and waist circumference [29]. Metabolites of phthalates are known as peroxisome receptor ligands proliferators (PPARs), which affect glucose homeostasis, insulin secretion, serum lipid concentration, and the amount of visceral and subcutaneous fat. Weakening PPAR signalling paths through phthalates can lead to obesity and diabetes mellitus [32]. To observe this, we divided children into the four categories: underweight, normal weight, overweight, and obese [33]. Although we did not observe any statistically significant differences between subgroups, we detected higher concentrations of MnBP, $\mathrm{MiBP}$, and MEP in obese children in comparison with normal weight or underweight children. Our results are comparable with U.S. studies [28, 34], where higher concentrations of LMW phthalates were detected in a group of overweight children [28], and no association was found between DEHP metabolites and obesity in children [34].

An important source of phthalate exposure is food ingestion [13], therefore we analysed some consumer practices 48 hours before urine sampling. We found statistically significant association between consumption of sliced salami packed in a plastic container and urinary concentrations of MEHP $(p=0.01)$, MEHHP $(\mathrm{p}=0.03), \operatorname{MEOHP}(\mathrm{p}=0.03)$, and $\operatorname{MECPP}(\mathrm{p}=0.04)$ and in the group of children $(\mathrm{n}=11 ; 21.57 \%)$. Higher concentrations of MEHHP were detected in the group of children $(n=6 ; 11.76 \%)$ who consumed a sandwich or baguette $(\mathrm{p}=0.03)$. We detected significantly higher concentrations of $\mathrm{MiBP}(\mathrm{p}=0.05)$, MEHHP $(\mathrm{p}=0.04)$, and McMHP $(\mathrm{p}=0.04)$ in adults $(\mathrm{n}=8$; $38.10 \%$ ) who drank milk or acidophilic milk. Our results are comparable with researches of food monitoring [35-37]. We observed similar patterns in these studies, where the highest concentrations of phthalate metabolites, mainly DEHP metabolites, were detected in the fat-rich food samples such as salami, cheese, milk, butter, or margarine. Phthalate lipophilicity was also documented in an Israeli study [38] that compared the concentrations of phthalates between 
Table 4. Comparison of phthalate metabolites $\left(\right.$ ng. $\left.\mathrm{ml}^{-1}\right)$ between girls and boys.

\begin{tabular}{|c|c|c|c|c|c|c|c|c|}
\hline & & MEP & $\mathrm{MnBP}$ & $\mathrm{MiBP}$ & MEHHP & MECPP & MEOHP & MEHP \\
\hline \multirow{2}{*}{ Our research (2017) Slovakia } & Boys $(n=32)$ & 23.71 & 53.90 & 32.77 & 18.79 & 12.59 & 15.95 & 2.36 \\
\hline & Girls $(\mathrm{n}=19)$ & 23.43 & 54.11 & 27.79 & 14.88 & 10.91 & 13.44 & 1.78 \\
\hline \multirow{2}{*}{$\begin{array}{c}\text { Rocha et al., [25] } \\
\text { Brazil }\end{array}$} & Boys $(\mathrm{n}=149)$ & 47.50 & 41.20 & 41.60 & 26.40 & 56.80 & 20.30 & - \\
\hline & Girls $(\mathrm{n}=151)$ & 67.70 & 43.60 & 47.90 & 22.90 & 45.40 & 14.80 & - \\
\hline \multirow{2}{*}{$\begin{array}{c}\text { Calafat et al., [24] } \\
\text { USA }\end{array}$} & Boys $(\mathrm{n}=73)$ & 20.00 & 12.60 & 10.60 & 11.30 & 22.20 & 7.70 & 1.00 \\
\hline & Girls $(n=49)$ & 13.30 & 7.50 & 5.50 & 6.80 & 12.80 & 4.60 & 0.70 \\
\hline \multirow{2}{*}{$\begin{array}{c}\text { Meeker and Fergusson [26] } \\
\text { USA }\end{array}$} & Boys $(n=1110)$ & 25.40 & 16.30 & 11.10 & 14.00 & 24.60 & 9.80 & 2.10 \\
\hline & Girls $(n=1098)$ & 30.10 & 17.60 & 13.10 & 14.80 & 26.10 & 10.00 & 1.84 \\
\hline \multirow{2}{*}{$\begin{array}{l}\text { Langer et al., [23] } \\
\text { Denmark }\end{array}$} & Boys $(n=240)$ & 15.50 & 78.80 & 69.20 & 33.40 & 36.10 & 18.00 & 4.70 \\
\hline & Girls $(\mathrm{n}=201)$ & 17.90 & 85.00 & 75.20 & 33.20 & 33.80 & 17.40 & 4.90 \\
\hline \multirow{2}{*}{$\begin{array}{l}\text { Wang et al., [22] } \\
\text { China }\end{array}$} & Boys $(n=130)$ & 15.60 & 44.70 & 35.50 & 16.70 & 32.20 & 27.50 & 21.60 \\
\hline & Girls $(\mathrm{n}=129)$ & 15.00 & 50.40 & 42.50 & 14.80 & 26.20 & 21.10 & 21.00 \\
\hline \multirow{2}{*}{ Teitelbaum et al., [28] USA } & Boys $(\mathrm{n}=80)$ & 191.20 & 68.60 & 22.00 & 76.60 & 126.90 & 50.70 & 6.70 \\
\hline & Girls $(\mathrm{n}=299)$ & 168.40 & 47.20 & 16.80 & 72.00 & 97.80 & 36.20 & 5.70 \\
\hline \multirow{2}{*}{$\begin{array}{c}\text { Boas et al., [27] } \\
\text { Denmark }\end{array}$} & Boys & 21.00 & 130.00 & - & 37.00 & 30.00 & 19.00 & 4.50 \\
\hline & Girls & 21.00 & 121.00 & - & 31.00 & 27.00 & 16.00 & 3.60 \\
\hline
\end{tabular}

Legend: MEP - monoethyl phthalate, MnBP - mono-n-buthyl phthalate, MiBP - mono-iso-buthyl phthalate;

MEHHP - mono(2-ethyl-5-hydroxyhexyl) phthalate, MECPP - mono(2-ethyl-5-carboxypentyl) phthalate;

MEOHP - mono(2-ethyl-5-oxohexyl) phthalate, MEHP - mono(2-ethylhexyl) phthalate

vegetarian/vegan and nonvegetarian nutrition. Their results showed that lower concentrations of MEHHP, MEOHP, and MiNP were associated with alternative nutrition, without consumption of dairy and meat products. In the next steps, probands were grouped according to plastic food foil usage. We detected significantly higher concentrations of metabolite MnBP $(p=0.02)$ in the group of children $(n=13 ; 25.49 \%)$ who consumed food packed in a plastic food foil at least twice a week in comparison with a lower usage frequency. Our study is not in accordance with food monitoring [37], where no association between higher concentrations of LMW phthalates and plastic food packaging was detected. On the other hand, they observed the higher concentrations of HMW phthalates in probands with plastic food packaging use.

Our study has some limitations. The weakness of our work is the size of a cohort of 78 probands, which is small compared to world studies. The second limitation is that some of the questionnaires were not fully completed.

\section{Conclusions}

Our study examined the associations between consumer practices and phthalate metabolite concentrations in a cohort of children and their parents.
We conclude that consumer practices, region of living, socioeconomic status, and age could affect urinary concentrations of phthalate metabolites in parents and their children.

\section{Acknowledgements}

This study was supported as a project of the Ministry of Health of SR No. 2016/9-UKFN-1, UGA VIII/24/2017. We thank Michaela Földesiova for excellent technical assistance.

\section{Conflict of Interest}

The authors declare no conflict of interest.

\section{References}

1. BIRNBAUM L., SHUG T.T. Phthalates in our food. Endocr. Disruptors. 1 (1), 1, 2013.

2. FERGUSON K.K., PETERSON K.E., LEE J.M., MERCADO - GARCIA A., BLANK-GOLDENBERG C., TÉLLEZ - ROJO M.M., MEEKER J.D. Prenatal and Peripubertal Phthalates and Bisphenol-A in Relation to Sex Hormones and Puberty in Boys. Reprod. Toxicol. 47, 70, 2014. 
3. SWAN S.H., SATHYANARAYANA S., BARRETT E.S., JANSSEN S., LIU F., NQUYEN R.H., REDMON J.B., TIDES STUDY TEAM. First trimester phthalate exposure and anogenital distance in newborns. Hum. Reprod. 30 (4), 963, 2015.

4. SWAN S.H., LIU F., HINES M., KRUSE R.L., WANG C., REDMON J.B., SPARKS A., WEISS, B. Prenatal phthalate exposure and reduced masculine play in boys. Int. J. Androl. 33 (2), 259, 2009.

5. BORNEHAG C.G., SUNDELL J., WESCHLER C.J., SIGSGAARD T., LUNDGREN B., HASSELGREN M., HÄGERHED - ENGMAN L. The Association between Asthma and Allergic Symptoms in Children and Phthalates in House Dust: A Nested Case-Control Study. Environ. Health Perspect. 112 (14), 1393, 2004.

6. NEWBOLD R.R. Impact of environmental endocrine disrupting chemicals on the development of obesity. Hormones. 9 (3), 206, 2010.

7. RUSYN I., CORTON J.C. Mechanistic considerations for human relevance of cancer hazard of di(2-ethylhexyl) phthalate. Mutat. Res. 750 (2), 141, 2012.

8. Endokrinní disruptory (ECDs) ve výrobcích a materiálech použivaných pro děti a dětmi. Available online: http:// is.muni.cz/th/426946/prif_m/ (accessed on 15. 09.2017).

9. YEN T.H., LIN-TAN D.T., LIN J.L. Food safety involving ingestion of foods and beverages prepared with phthalateplasticizer-containing clouding agents. J. Formos. Med. Assoc. 110, 671, 2011.

10. LATINI G. Monitoring phthalate exposure in humans. Clin. Chim. Acta. 361, 20, 2005.

11. WORMUTH M., SCHERINGER M., VOLLENWEIDER M., HUNGERBÜHLER K. What Are the Sources of Exposure to Eight Frequently Used Phthalic Acid Esters in Europeans? Risk Anal. 26 (3), 803, 2006.

12. VENTRICE P., VENTRICE D., RUSSO E., DE SARRO G. Phthalates: European regulation, chemistry pharmacokinetics and related toxicity. Environ. Toxicol. Pharmacol. 33 (1), 88, 2013.

13. MIKULA P., SVOBODOVÁ Z., SMUTNÁ M. Phthalates: Toxicology and Food Safety - a Review. Czech J. Food Sci. 23 (6), 217, 2005.

14. PILKA T., PETROVIČOVÁ I., KOLENA B., ZAŤKO T., TRNOVEC T. Relationship between variation of seasonal temperature and extent of occupational exposure to phthalates. Environ. Sci. Pollut. Res. Int. 22 (1), 434, 2015.

15. GREEN R., HAUSER R., CALAFAT A.M., WEUVE J., SCHETTLER T., RINGER, S., HUTTNER K., HU H. Use of Di(2-ethylhexyl) Phthalate-Containing Medical Products and Urinary Concentrations of Mono(2ethylhexyl) Phthalate in Neonatal Intensive Care Unit Infants. Environ. Health Perspect. 113 (9), 1222, 2005.

16. GINSBERG G., SLIKKER W., BRUCKNER J., SONAWANE B. Incorporating Children's Toxicokinetics into a Risk Framework. Environ. Health Perspect. 112, 272, 2003.

17. LARSSON K., LJUNG BJÖRKLUND, K., PALM B., WENNBERG M., KAI L., LINDH C. H., JÖNSSON B.A., BERGLUND M. Exposure determinants of phthalates, parabens, bisphenol A and triclosan in Swedish mothers and their children. Environ. Int. 73, 323, 2014.

18. FREDERIKSEN H., NIELSEN J.K., MORCK T.A., HANSEN P.W., JENSEN J.F., NIELSEN O., ANDERSSON A.M., KNUDSEN L.E. Urinary excretion of phthalate metabolites, phenols and parabens in rural and urban Danish mother-child pairs. Int. J. Hyg. Environ. Health. 216, 772, 2013.
19. =CASAS L., FERNÁNDEZ M.F., LLOP S., GUXENS M., BALLESTER F., OLEA N., IRURZUN M.B., RODRÍGUEZ L.S., RIAÑO I., TARDÓN A., VRIJHEID M., CALAFAT A.M., SUNYER J. Urinary concentrations of phthalates and phenols in a population of Spanish pregnant women and children. Environ. Int. 37, 858, 2011.

20. KASPER-SONNENBERG M., KOCH H.M., WITTSIEPE J., WILHELM M. Concentrations of phthalate metabolites in urine among mother-child-pairs - Results from the Duisburg birth cohort study, Germany. Int. J. Hyg. Environ. Health. 215, 373, 2012.

21. WITTASSEK M., ANGERER J. Phthalates: metabolism and exposure. Int. J. Androl. 31, 131, 2008.

22. WANG C., XIE L., ZHOU K., ZHAN Y., LI Y., LI H., QIAO L., WANG F., HUA Y. Increased Risk for Congenital Heart Defects in Children Carrying the ABCB1 Gene C3435T Polymorphism and Maternal Periconceptional Toxicants Exposure. PLoS ONE. 8 (7), 1, 2013.

23. LANGER S., BEKÖ G., WESCHLER C.J., BRIVE L.M., TOFTUM J., CALLESE M., CLAUSEN G. Phthalate metabolites in urine samples from Danish children and correlations with phthalates in dust samples from their homes and day care centers. Int. J. Hyg. Environ. Health. 217, 78, 2014.

24. CALAFAT A.M., YE X., VALENTINI-BLASINI L., LI Z., MORTENSEN M.E., WONG L.Y. Co-exposure to nonpersistent organic chemicals among American pre-school aged children: A pilot study. Int. J. Hyg. Environ. Health. 220 (2), 55, 2017.

25. ROCHA B.A., ASIMAKOPOULOS A.G., BARBOSA F. JR., KANNAN K. Urinary concentrations of 25 phthalate metabolites in Brazilian children and their association with oxidative DNA damage. Sci. Total Environ. 586, 152, 2017.

26. MEEKER J.D., FERGUSON K.K. Urinary Phthalate Metabolites Are Associated With Decreased Serum Testosterone in Men, Women, and Children From NHANES 2011-2012. J. Clin. Endocrinol. Metab. 99, 4346, 2014.

27. BOAS M., FREDERIKSEN H., FELDT-RASMUSSEN U., SKAKKEBÆK N.E., HEGEDÜS L., HILSTED L., JUUL A., MAIN K.M. Childhood Exposure to Phthalates: Associations with Thyroid Function, Insulin-like Growth Factor I, and Growth. Environ. Health Perspect. 118 (10), 1458, 2010.

28. TEITELBAUM S.L., MERVISH N., MOSHIER E., VANGEEPURAM N., GALVEZ M.P., CALAFAT A.M., SILVA M.J., BRENNER B., WOLFF M.S. Associations between Phthalate Metabolite Urinary Concentrations and Body Size Measures in New York City Children. Environ. Res. 112, 186, 2012.

29. ÚPSVaR. Nezamestnanost' - mesačné štatistiky. Available online:http://www.upsvar.sk/statistiky/nezamestnanostmesacne-statistiky/kopia-2016.html?page_id $=671750$ (accessed on 07. 11. 2017).

30. SONG N.R., ON J.W., LEE J., PARK J.D., KWON H.J., YOON H.J., PYO H. Biomonitoring of urinary di(2ethylhexyl) phthalate metabolites of mother and child pairs in South Korea. Environ. Int. 54, 65, 2013.

31. WU W., ZHOU F., WANG Y., NING Y., YANG J.Y., ZHOU Y.K. Phthalate concentrations and related factors in children aged 6-12 years. Environ. Pollut. 220, 990, 2017.

32. LIND P. M., ZETHELIUS B., LIND L. Circulating Concentrations of Phthalate Metabolites Are Associated With Prevalent Diabetes in the Elderly. Diabetes Care. 35, 1519, 2012. 
33. CDC. Body Mass Index (BMI). Available online: https:// nccd.cdc.gov/dnpabmi/Calculator.aspx (accessed on 20. 09. 2017).

34. TRASANDE L., ATTINA T. M., SATHYANARAYANA S., SPANIER A.J., BLUESTEIN J. Race/Ethnicity-Specific Associations of Urinary Phthalates with Childhood Body Mass in a Nationally Representative Sample. Environ. Health Perspect. 121, 501, 2013.

35. SERRANO S.E., BRAUN J., TRASANDE L., DILLS R., SATHYANARAYANA S. Phthalates and diet: a review of the food monitoring and epidemiology data. Environ. Health. 13, 1, 2014.

36. VAN HOLDERBEKE M., GEERTS L., VANERMEN G., SERVAES K., SIOEN I., DE HENAUW S., FIERENS T. Determination of contamination pathways of phthalates in food products sold on the Belgian market. Environ. Res. 134, 345, 2014.

37. SAKHI A. K., LILLEGAARD I.T., VOORSPOELS S., CARLSEN M.H., LØKEN E.B., BRANTSÆR A.L., HAUGEN M., MELTZER H.M., THOMSEN C. Concentrations of phthalates and bisphenol $\mathrm{A}$ in
Norwegian foods and beverages and estimated dietary exposure in adults. Environ. Int. 73, 259, 2014.

38. TORDJMAN K., GRINSHPAN L., NOVACK L., GÖEN T., SEGEV D., BEACHER L., STERN N., BERMAN T. Exposure to endocrine disrupting chemicals among residents of a rural vegetarian/vegan community. Environ. Int. 97, 68, 2016.

39. MYRIDAKIS A., FTHENOU E., BALASKA E., VAKINTI M., KOGEVINAS M., STEPHANOU E.G. Phthalate esters, parabens and bisphenol-A exposure among mothers and their children in Greece (Rhea cohort). Environ. Int. 83, 1, 2015.

40. POLANSKA K., LIGOCKA D., SOBALA W., HANKE W. Phthalate exposure and child development: The Polish Mother and Child Cohort Study. Early Hum. Dev. 90, 477, 2014.

41. ENKE U., SCHLEUSSNER E., PÄLMKE C., SEYFARTH L., KOCH H.M. Phthalate exposure in pregnant women and newborns - the urinary metabolite excretion pattern differs distinctly. Int. J. Hyg. Environ. Health 216, 735, 2013. 